\title{
Soft skills development in personnel training
}

\author{
Maria Kupryaeva ${ }^{1}$, Oksana Mamai $^{1}$, Lyubov Panofenova ${ }^{2 *}$, Svetlana Syreskina ${ }^{1}$, and Nelli \\ Chigina $^{1}$ \\ ${ }^{1}$ Samara State Agrarian University, Uchebnaya str., 2, Kinel, urban-type settlement Ust-Kinelsky, \\ 446442, Russia \\ ${ }^{2}$ Limited Liability Company «Volga Region Center Of Professional Development «Dynasty», \\ Melnichnaya str., Samara, 443015, Russia
}

\begin{abstract}
The relevance and demand of graduates on a labor market, ability to adapt quickly to employer's requirements or to change specialty in a short period of time are one of the main aspects that are becoming more and more important and necessary. It is connected with the growing amount of information and the increase of uncertainty level. The development of soft skills (together with professional skills) of students helps to improve flexibility, prompt reaction, and speed of decisionmaking as well as sensitivity, system solution. So, as a result there is a stable personality and a professional employee. The article presents the research on soft skills development of undergraduate students from Samara State Agrarian University. The obtained results have shown the relevant ways, approaches and methods for development of soft skills. The recommendations for soft skills development for students have been also analyzed. It has been proved that additional education, especially connected with the foreign languages, contributes to the development of the following soft skills: multilingualism and multiculturalism, the ability to work with people, the ability to work under unstable conditions, creative thinking and flexibility of behavior.
\end{abstract}

\section{Introduction}

Hard skills are developed in the course of professional education. They can be easily measured and trained and form the core base for necessary professional competences.

Soft skills are getting more and more relevant in the modern world. They are the universal skills that are formed throughout life period in the family and then in society. They contribute to the quick social and professional inclusion of the graduates in a new workplace or to the quick professional change. All these lead to the increase competitiveness of the graduate at the labor market. There are a lot of terms that define soft skills: life skills, flexible skills, over-professional skills.

Soft skills are the skills of the $21^{\text {st }}$ century. Although the first research devoted to the soft skills were presented at the CONARC Soft Skills Conference in the 1970s in the West, their importance is growing nowadays. New methods and approaches have been developed. A lot of researchers in this field define the influence of soft skills on career path and going

*Corresponding author: 163dynasty@gmail.com 
up the career ladder. The mastering and development of extra soft skills allows to open up new opportunities in the professional sphere.

Approaches to assessment methodology of soft skills have not been well developed in contrast with the professional skills evaluation [1]. Nevertheless the level of development of employee's one type of soft skills or the other influences the employer's final decision. It proves the relevance of systematic soft skills development in the personnel training for the increase of employee's competitiveness at the labor market. There is a number of fundamental scientific papers dedicated to the soft skills and the professions of the future: "Atlas of the professions of the future" developed by the Agency of strategic innovations [2] and reports of company group (including Sberbank and WorldSkills Russia) "Russia 2025: from human resources to talents" [3].

The soft skills are divided according to "the Atlas" into the following:

System thinking,

Intersectoral communication,

Multilingualism and multiculturalism (fluent English language and the second language competence, the understanding and awareness of national and cultural context of partner countries, the awareness of professional sphere in other countries)

Project management

Customer focus

Lean production

Ecological thinking

Programming/ Robot technology/ Artificial intelligence

Communication skills

Ability to work under uncertainty

Art skills [2].

There exist a number of scientific works related to the formation and development of soft skills, e.g.: Pavlova J. [4], Zatsepina O., Kuptsova O. [5] (soft skills in the area of training "Linguistics"); Sadullaev Kh. [6], Ogareva E., Lik N. [7], Nikolaeva T., Taranova O. [8] (the development of soft skills in school, higher education and post-graduate education).

Many of the scientists highlight the most important soft skills such as:

System thinking;

Flexibility of mind [2, 3, 9, 10]; Critical thinking [2, 9-11]; Creative thinking [2, 9]; People/Personnel management $[9,10]$.

So, the modern teaching methodology should be focused on the students' creative skills development, on the abilities of independent search of necessary information, on the independent analysis of the information, on the abilyty to express one's own opinion. To conclude, the educationsl process should be centered around the search and creation of new senses.

\section{Materials and methods}

Special interest and attention to the soft skills development from the scientists and employers is caused by the growth of uncertainty level and rapid changes in the modern world. There are the main qualities that are becoming more and more relevant and crusial for the labor market today: the ability to orientate oneself in the increasing flow of information, quick decision making, flexibility, sensitivity, communication skills, creativity, self-confidence, being convincing.

The increasing flow of information greatly influences on the person's mind and thinking. As a result goal settings have been transformed, the meanings of professional activity are gradually distorted, as well as the meaning of life. Consequently, a person 
becomes emotionally and psychologically instable, and it negatively influences the health [12].

Radical changes of the professions of the future happened after the information revolution and technological revolution according to American philosopher Toffler who wrote about it in 1970. There has been a gradual increase in intellectualization and informatization of professions since then. The main goal of the national project "Labor productivity" - "Decent, Effective Work and Successful Entrepreneurship" [13].

The research on the perspectives of new professions for agricultural industry carried out by the Agency for strategic initiatives (in accordance with the Atlas of new professions) has revealed the following:

in the field of management there is going to be a demand for specialists with good organizational skills, able to create new sustainable systems that will develop in longlasting perspective and provide a stable income. Professionals from management field will be on demand in different areas. It is necessary to develop system thinking and flexible thinking and quick decision-making skills.

Future professionals in the field of agricultural industry will also require the development and mastering of organizational skills, system thinking, ecological thinking, as well as knowledge in the area of innovative entrepreneurship and modern information technologies [2].

\subsection{The research on soft skills development}

The purpose of the research was to develop necessary soft skills in personnel training in the agricultural industry sector. The research was conducted by the teaching staff at the Samara State Agrarian University (SSAU). First, second and third-year full-time students have participated in the research.

The aim of the research is to reveal the relevant ways, approaches and methods of teaching for formation and development of soft skills of the students from SSAU [14].

Statistical method, empirical methods and methods of experimental and theoretical analyses have been used.

182 students took part in the research:

60 first-year students,

55 second-year students,

67 third-year students of the Economics department, Engineering department, Technological department and Agricultural department.

At the beginning the level of students` soft skills development has been defined. It was carried out via interviewing and survey and the income case study task - problem task in the agricultural sector.

Table 1. Soft skills.

\begin{tabular}{|c|c|}
\hline № & Skill \\
\hline 1 & System thinking \\
\hline 2 & Multilingualism and multiculturalism \\
\hline 3 & Project management \\
\hline 4 & Lean production \\
\hline 5 & Ecological thinking \\
\hline 6 & Communication skills \\
\hline 7 & Ability to work under uncertainty \\
\hline 8 & Art skills \\
\hline
\end{tabular}




\subsection{Evaluation results of the initial level of soft skills development}

The results of the initial level of soft skills development are shown in Fig. 1.



Fig. 1. The results of the initial level of soft skills development.

The analysis has revealed the natural soft skills development formed in the course of education process. The potential of soft skills development has been found. The development of the following soft skills are of great importance: project management, lean production, ability to work under uncertainty, ability to work with people, multilingualism and multiculturalism.

The study period lasted 1 term and involved the working educational programs on the academic disciplines "The Foreign Languages", "Business Communication", "Fundamentals of State and Municipal Administration". The teachers developed and implemented additional methods and techniques for practical classes for soft skills development:

1. group tasks on project work and on team building

2. case study tasks /problem solving tasks

3. participation in various grants, competitions and forums

Apart from the main study group chosen for the analysis of soft skills development, one special group of 17 full-time students (out of 182 students) from the additional training program "Interpreter in the Field of Professional Communication" (in the Language Centre of SSAU) was chosen.

\section{Results}

The results on the final level of soft skills development are presented in Fig. 2. 


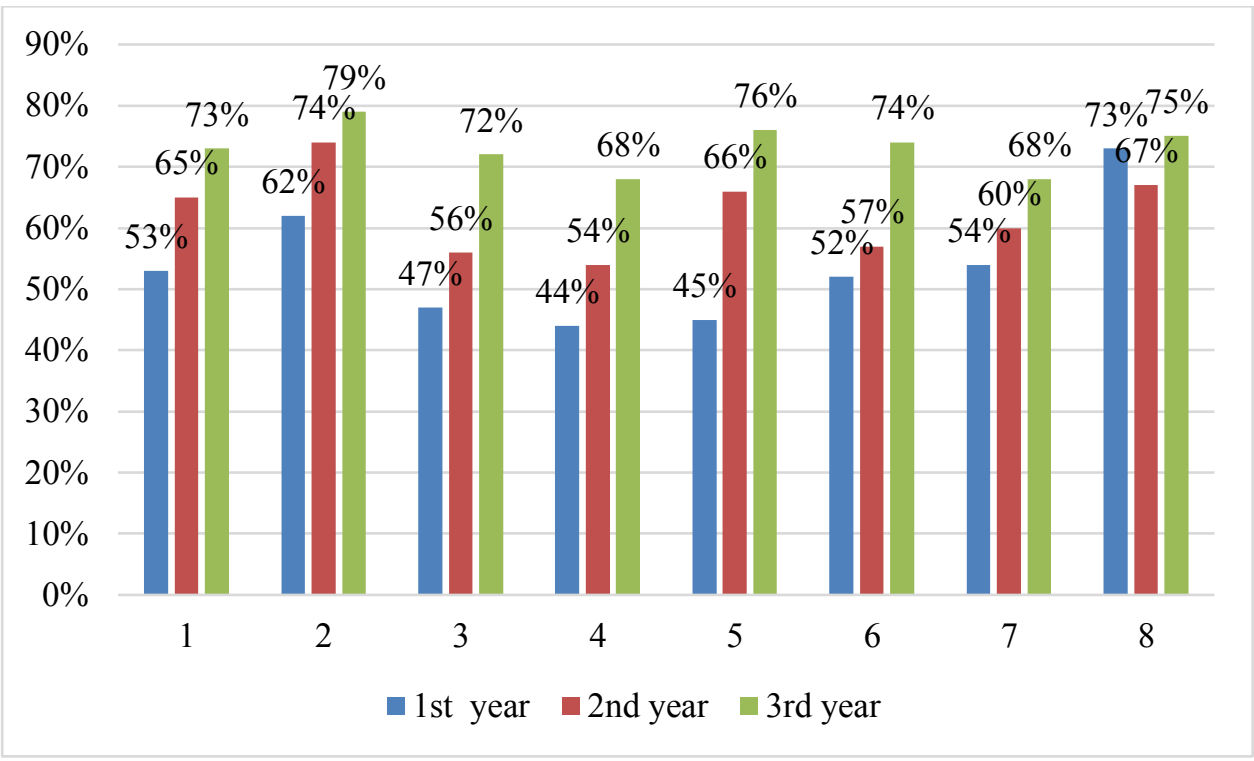

Fig. 2. The final level of soft skills development (the main study group).

The study has revealed that the students who get additional education on the program "Interpreter in the Field of Professional Communication"» develop soft skills 7-11\% faster than the students who do not get additional education (Fig. 3). Among these soft skills are the following:

Multilingualism and multiculturalism;

System thinking;

Project management;

Customer focus;

Good communication skills;

Ability to work under uncertain conditions;

Art and creative skills (skills of finding way-out solutions, skills of creative problemsolving).

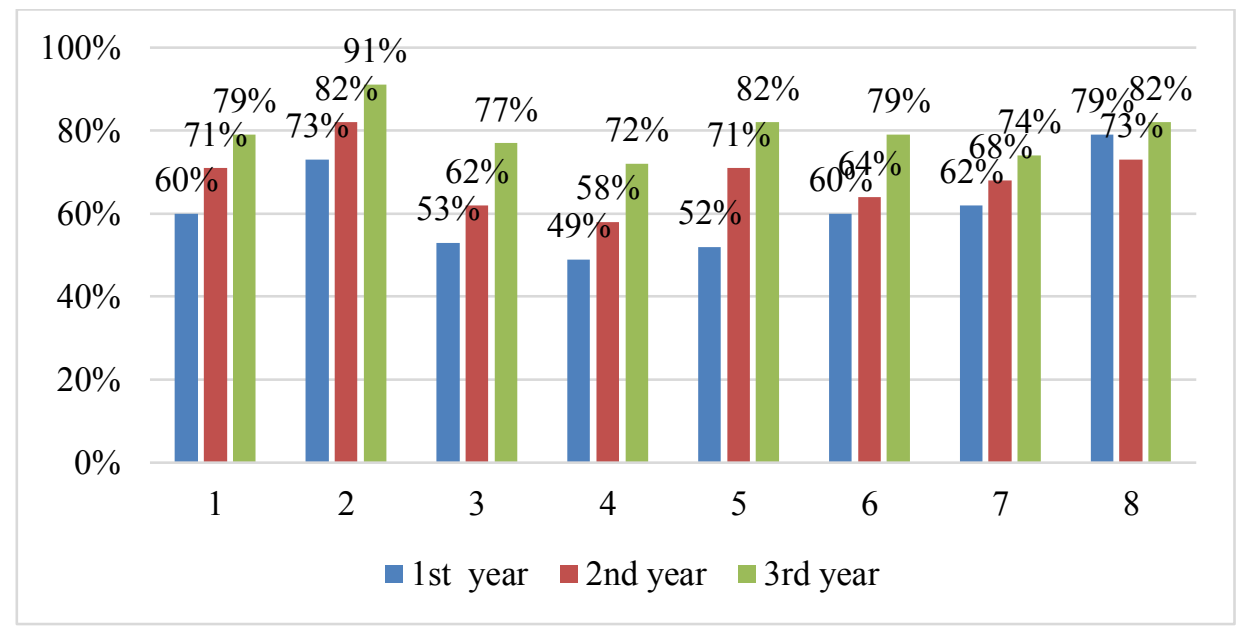

Fig. 3. The final level of soft skills development (the special group of 17 students out of the main group). 


\section{Discussion}

The results obtained can be applied to the teaching process for students of SSAU as well as other higher educational institutions for students, their successful career planning and career development. It is also useful for independent soft skills development. As for education process, the education programs can be modified according to the soft skills development.

In order to develop soft skills in personnel training successfully, a several steps should be implemented: tasks;

- to use modern teaching methods: case study, project work, gaming techniques, group

- to involve students into participation in different projects, competitions, grants? forums (preferably through the mentor system). The mentor can be a teacher, a senior student with proactive life position.

Additional educational training programs improves the flexibility of a graduate and opens more opportunities and possibilities in career prospectus.

Besides soft skills development, a great attention should be give to the issues of selfidentification, goal sittings in the sphere of a future profession and a complex approach to the teaching and student involvement in extra-curriculum activities: additional education or training, apprenticeship, participation in grants, forums and competitions. As the practically applied activity contributes to the gaining of practical experience in the project work, its presentation and defense procedure, then it helps to solve issues of self-identification.

The efficiency of soft skills developments can be achieved if the following conditions are kept: at first it is necessary to solve the questions and problems concerning the personal stability:

Factors influencing personal stability are the following:

frame of value references;

traditions;

national culture issues;

stable position of parents, family and generation;

issues concerning faith and convictions;

self-acceptance and acceptance of parents, family and generation;

chosen issues and questions concerning the self-acceptance through family traditions, care about yourself, health and family [15].

The above-mentioned factors allows to develop a proactive life position of a person.

\section{References}

1. M.V. Timoshkina, S.S. Kvatch, A.A. Karminsky, Business. Education. Law, 1, 373378 (2021), DOI: 10.25683/VOLBI.2021.54.118.

2. D. Varlamova, D. Sudakova (ed.), Atlas of New Professions 3.0. (Intellectual Literature, Moscow, 2020)

3. Perspectives of labor market development, employment skills and strategies under conditions of the 4th industrial revolution. Global challenges. World Economics Forum, p. 197 (2016)

4. J.V. Pavlova, Professional Communication: Current Issues on Linguistics and Methods of Teaching, 11, 147-154 (2018) 
5. O.V. Zatsepina, E. J. Kuptsova, The students 'soft skills development in the course of self-study in the Internet environment based on the programme "Foreign Language»). Higher School: Experience, Problems and Perspectives, by ed. V.I. Kazarenkov, in Proceedings of XI International Conference, pp. 393-396 (2018)

6. H.H. Sadullaev, Soft skills: students 'attitude to the soft skills development. MHCK2018: Management, In Proceedings of the 56th International Student Conference, Novosibirsk, pp. 25-26 (2018)

7. E.I. Ogareva, N.V. Lik, In Proceedings of the International Conference of RANEPA 1, 145-149 (2018)

8. T.V. Nikolaeva, O.L. Taranova, Soft skills development at the English language lessons, in Proceedings of Coss-Cultural Communication and Professionaly-Oriented Foreign Language Learning: All-Russian Conference, pp. 166-169 (2019)

9. Professional Skills of the Future - 2020, p.19 (Institute of Strategic Research, Phoenix, 2011)

10. Perspectives of labor market development, employment skills and strategies under conditions of the 4th industrial revolution. Global challenges. World Economics Forum, p. 197 (2016)

11. Russia 2025: from human resources to talents. Boston consulting group. Official partners of the research: Sberbank, charitable foundation by Sberbank "Contributions to the Future", the Unity of Young Professionals, Global Education Future (2017)

12. V.V. Likholetov, L.V. Ljvov, E.V. Godlevskaya, Modern Higher School: Innovative Aspect, 2(48) (2020), URL: https://cyberleninka.ru/article/n/o-professiyahbuduschego-nadprofessionalnyh-navykah-i-problemah-modelirovaniya-v-sfereprofessionalnogo-obrazovaniya. Accessed 24.02.2021

13. https://roscongress.org/en/knowledge/natsionalnyy-proekt-proizvoditelnost-truda-ipodderzhka-zanyatosti/materials/ - The National Project "Labor Productivity and Employment Support"

14. https://free-apply.com/en/university/1064300904 - the website of Samara State Agrarian University

15. J. Korobkova, L. Panofenova, O. Pervova, Science of Krasnojarie, 9(2), 78-90 (2020), doi: $10.12731 / 2070-7568-2020-2-78-90$ 